\title{
Postnatal Lung Inflammation Increased by Ventilation of Preterm Lambs Exposed Antenatally to Escherichia coli Endotoxin
}

\author{
MACHIKO IKEGAMI AND ALAN H. JOBE \\ Cincinnati Children's Hospital Medical Center, Division of Pulmonary Biology, \\ Cincinnati, Ohio 45229, U.S.A.
}

\begin{abstract}
ABST
Chorioamnionitis resulting in exposure of the fetal lung to
inflammation is frequent before preterm delivery. The initiation
of mechanical ventilation in the preterm recruits granulocytes to
the lungs and increases proinflammatory cytokine expression in
the lungs. We hypothesized that when the prematurely born
newborn with chorioamnionitis was ventilated, inflammation
would increase. Therefore, we asked whether inflammatory ex-
posure to the fetal lung caused by intra-amniotic endotoxin (10
mg, Escherichia coli 055: $\beta 5$ ) given at $100 \mathrm{~d}$ gestation would
alter the inflammatory responses to the mechanical ventilation in
surfactant-treated preterm lambs delivered at $130 \mathrm{~d}$ gestation.
Cells in alveolar washes, proinflammatory cytokine expression,
and surfactant protein mRNA expression were not different for
saline and endotoxin exposed lambs that were not ventilated. The
endotoxin- and saline-exposed control animals had similar lung
function for 6 h of ventilation. Bronchoalveolar lavage fluid from
the ventilated and antenatal endotoxin-exposed animals con-
\end{abstract}
tained 5.7 times more monocytes, 12 times more lymphocytes, and a nonsignificant increase in neutrophils. Cells from the bronchoalveolar lavage fluid expressed 3-fold more IL-6 and IL-8 mRNA than did cells from the saline exposed comparison animals. An antenatal exposure of the fetal lung to endotoxin enhanced the subsequent inflammatory response of the ventilated preterm lung. (Pediatr Res 52: 356-362, 2002)
Abbreviations
BPD, bronchopulmonary dysplasia
$\mathrm{FIO}_{2}$, fraction of inspired oxygen
PEEP, positive end-expiratory pressure
PIP, peak inspiratory pressure
VT, tidal volume
VEI, ventilatory efficacy index
Sat PC, saturated phosphatidylcholine
BALF, bronchoalveolar lavage fluid

The most common chronic pulmonary complication of very preterm birth is BPD. In recent pathologic reports, BPD is characterized by decreased alveolar development resulting in large saccular airspaces (1-3) that are thought to result from the superposition of injury on the developing lung (4). Similar morphologic alterations with alveolar hypoplasia, variable amounts of saccular wall fibrosis, and dysmorphic capillary development occur in oxygen-exposed newborn mice and ventilated preterm baboons and sheep (5-7). Although there are differences in the histopathology of BPD before the era of surfactant treatment and newer approaches to more gentle ventilation of preterm infants and more recent descriptions of $\operatorname{BPD}(1,3)$, inflammation appears to be a common factor $(8)$. Airway aspirates from infants that develop BPD contain indi-

Received October 4, 2001; accepted February 28, 2002

Correspondence: Machiko Ikegami, M.D., Ph.D., Cincinnati Children's Hospital Medical Center, Division of Pulmonary Biology, 3333 Burnet Avenue, Cincinnati, OH 45229-3039, U.S.A.; e-mail: machiko.ikegami@chmcc.org

Supported by grant HD 12714 from the National Institute of Health and Human Services. Surfactant Venticute provided by Byk Gulden, Konstanz, Germany.

DOI: 10.1203/01.PDR.0000030715.99576.E7 cators of inflammation such as granulocytes and proinflammatory cytokines soon after birth $(8-10)$, as do airway samples from preterm ventilated baboons that develop BPD (5). Therefore, a hypothesis for the development of BPD is that inflammation resulting from mechanical ventilation and supplemental oxygen treatment interferes by yet-to-be-defined mechanisms with lung development and injury repair (11). We recently demonstrated that the initiation of ventilation of the preterm lung by mechanical ventilation with $\mathrm{V}_{\mathrm{T}}$ of $9-11 \mathrm{~mL} / \mathrm{kg}$ recruited granulocytes to the lungs and induced mRNA expression of IL- $1 \beta$, IL-6, and IL-8 in the preterm lung (12). This result demonstrated that the proinflammation known to correlate with BPD was activated by the initiation of ventilation (5, $8-10,13)$.

Another source of inflammatory injury to the preterm lung is antenatal chorioamnionitis (4). Many deliveries before $30 \mathrm{wk}$ gestation are exposed to a chronic asymptomatic chorioamnionitis that bathes the fetus in amniotic fluid containing proinflammatory cells and cytokines (14). Histologic chorioamnionitis in humans is associated in some reports with a decrease in respiratory distress syndrome but a subsequent increase in BPD 
(15-17). Intra-amniotic endotoxin given before preterm delivery in sheep induces inflammatory cell recruitment to the chorioamnion, increased granulocytes in amniotic fluid, and proinflammatory cytokine expression. The response of the fetal sheep lung to intra-amniotic endotoxin is a recruitment of granulocytes, hydrogen peroxide production, and proinflammatory cytokine expression $(18,19)$. Intra-amniotic endotoxininduced chorioamnionitis in sheep results in indicators of lung maturation such as increased lung gas volumes and increased surfactant but with decreased alveolarization after preterm birth $(20,21)$. In the adult animal, exposure of the lung to endotoxin before mechanical ventilation results in augmented inflammatory responses $(22,23)$.

We hypothesized that an antenatal inflammatory exposure would prime the fetal lung to respond with an amplified inflammatory response to the initiation of ventilation after preterm birth. To test for residual effects of endotoxin-induced inflammation and chorioamnionitis, we exposed fetal sheep to intra-amniotic endotoxin $30 \mathrm{~d}$ before preterm delivery, ventilation, and evaluations of lung markers of inflammation. Lung markers of inflammation were chosen for this study from the clinical and animal studies that have associated BPD with inflammation $(5,8,13)$.

\section{METHODS}

Intra-amniotic endotoxin. Studies were performed with the approval of the Animal Care and Use Committee from Cincinnati Children's Hospital Medical Center, Cincinnati, OH, U.S.A. Suffolk ewes crossed with Dorset rams were randomized at $100 \mathrm{~d}$ gestation to receive intra-amniotic injections (I.A.) of $10 \mathrm{mg}$ Escherichia coli 055:B5 endotoxin (Sigma Chemical, St. Louis, MO, U.S.A.) in $2 \mathrm{~mL}$ saline or $2 \mathrm{~mL}$ saline alone. Endotoxin was shown previously to cause chorioamnionitis when given at $100 \mathrm{~d}$ gestation in sheep and the 10-mg dose caused both chorioamnionitis and lung maturation $(18,19)$. The intra-amniotic injections were done with ultrasound guidance and electrolyte analysis of aspirated samples of amniotic fluid was used to verify the intra-amniotic rather than allantoic location of the injection (21).

Delivery and ventilation of preterm lambs. Thirty days after the intra-amniotic injection at $100 \mathrm{~d}$ gestation, the premature lambs were delivered by cesarean section at $130 \mathrm{~d}$ gestation and randomized to $6 \mathrm{~h}$ ventilation ( $6 \mathrm{~h}$ Vent) or no ventilation (No Vent) groups. The No Vent lambs were given a pentobarbital overdose $(50 \mathrm{mg} / \mathrm{kg}$, i.v. $)$ at delivery and before breathing. For the $6 \mathrm{~h}$ Vent groups, each preterm lamb was given ketamine $(10 \mathrm{mg} / \mathrm{kg}$ intramuscularly) and acepromazine $(0.1$ $\mathrm{mg} / \mathrm{kg}$ intramuscularly) and intubated with a cuffed $4.5-\mathrm{mm}$ tracheal tube. Lung fluid was removed from the tracheal tube by aspiration and the tracheal tube was occluded with a clamp. After the umbilical cord was cut, the lamb was weighed, and surfactant (Venticute, Byk Gulden, Konstanz, Germany) (4 $\mathrm{mL} / \mathrm{kg}$ ) was instilled into the lungs and ventilation was initiated. Venticute $(25 \mathrm{mg} / \mathrm{mL})$ is a synthetic surfactant that contains $2 \%$ recombinant human surfactant protein (SP-C) in dipalmitoylphosphatidylcholine and palmitoyl/oleoylphosphatidylglycerol in a 70:30 wt/wt ratio and 5\% palmitic acid.
This surfactant performs similarly to natural surfactant in preterm animals $(24,25)$.

The initial ventilator settings were as follows: an $\mathrm{FiO}_{2}$ of 1.0; a respiratory rate of 40 breaths $/ \mathrm{min}$; an inspiratory time of $0.7 \mathrm{~s}$; a PEEP of $4 \mathrm{~cm} \mathrm{H}_{2} \mathrm{O}$, and a PIP sufficient to yield a VT of $8-9 \mathrm{~mL} / \mathrm{kg}$. This $\mathrm{V}_{\text {т }}$ was chosen to minimize lung injury with the initiation of ventilation (26). Vт measurements were made with a Fleisch pneumotachometer at $30 \mathrm{~min}, 1 \mathrm{~h}$, and every subsequent hour. Changes in $\mathrm{V}_{\mathrm{T}}$ were monitored continuously during ventilation (CP-100, Bicore Monitoring Systems, Anaheim, CA, U.S.A.). PIP and $\mathrm{FiO}_{2}$ were regulated to maintain a target $\mathrm{PCO}_{2}$ of $55 \mathrm{~mm} \mathrm{Hg}$ and a target $\mathrm{Po}_{2}$ of 150-200 mm Hg. A 5F catheter was advanced into the aorta via an umbilical artery, and a $10 \mathrm{~mL} / \mathrm{kg}$ transfusion of filtered fetal blood collected from the placenta was given within 10 min of delivery. Dynamic compliance was calculated as $\mathrm{V}_{\mathrm{T}}$ $(\mathrm{mL})$ normalized to body weight $(\mathrm{kg})$ and divided by the ventilatory pressure $\left(\mathrm{cm} \mathrm{H}_{2} \mathrm{O}\right)$, (PIP - PEEP). The ventilatory efficiency index (VEI) was calculated as [VEI $=3800 /$ respiratory rate $\left.\times(\mathrm{PIP}-\mathrm{PEEP}) \times \mathrm{P}_{2}\right]$, where 3800 is a $\mathrm{CO}_{2}$ production constant (27). The arterial catheter was used for blood gas analysis and blood pressure monitoring. Fluid containing $10 \%$ dextrose was infused through a leg vein at the rate of $4 \mathrm{~mL} / \mathrm{kg} / \mathrm{h}$. Rectal temperature was monitored and kept at $38-39^{\circ} \mathrm{C}$ with heating pads and radiant heat. Supplemental ketamine and acepromazine were given to prevent spontaneous breathing. After $6 \mathrm{~h}$, each animal was deeply anesthetized with $25 \mathrm{mg} / \mathrm{kg}$ pentobarbital i.v. The endotracheal tube was clamped for $3 \mathrm{~min}$ to permit oxygen absorption, and the animal was exsanguinated.

Pressure-volume curve and lung processing. The thorax of the lamb was opened, the lungs were inflated with air to $40 \mathrm{~cm}$ $\mathrm{H}_{2} \mathrm{O}$ pressure for 1 min and a maximum lung volume was recorded (25). The pressure was sequentially lowered to 20,15 , 10,5 and $0 \mathrm{~cm} \mathrm{H}_{2} \mathrm{O}$, and lung volumes ( $\mathrm{mL} / \mathrm{kg}$ body weight) were recorded after $30 \mathrm{~s}$ at each pressure. Left and right lung weights were recorded. Pieces of the right lower lobe were immediately frozen in liquid nitrogen for RNA isolation. Bronchoalveolar lavage of the left lung was with $0.9 \% \mathrm{NaCl}$ at $4^{\circ} \mathrm{C}$, and the lavage was repeated five times (19). The BALF was pooled and aliquots were saved for measurement of Sat PC, total protein (28), cell number and differential count, hydrogen peroxide production, and flow cytometry. Using left and right lung weight ratios, results using BALF were calculated for the total lung and normalized to kilograms of body weight.

Fetal lung fluid and BALF were centrifuged at $500 \times g$ for $10 \mathrm{~min}$ and the cell pellets were resuspended in PBS. Cells were stained with trypan blue and counted. Differential cell counts were performed on cytospin preparations after staining with Diff-Quick (American Scientific Products, San Diego, CA, U.S.A.). The activation state of the BALF cells was assessed by measuring hydrogen peroxide production for $1 \times$ $10^{6}$ cells using an assay based on the oxidation of ferrous iron $\left(\mathrm{Fe}^{2+}\right)$ to ferric iron $\left(\mathrm{Fe}^{3+}\right)$ by hydrogen peroxide under acidic conditions (Bioxytech $\mathrm{H}_{2} \mathrm{O}_{2}-560$ assay; OXIS International, Portland, OR, U.S.A.). The results are expressed as total alveolar cells normalized to $\mathrm{kg}$ body weight as described above. 
Aliquots of BALF cells were incubated on ice with MAb (primary antibody) against ovine $\mathrm{CD} 11 \mathrm{~b}$ (M subunit of integrin CR3) and CD44 (proteoglycan link protein). CD11b and CD44 are involved in the vascular-to-tissue migration of neutrophils and monocytes to sites of inflammation (29). CD14 also was measured because it is the receptor for the lipopolysaccharide and lipopolysaccharide binding protein complex. The cell pellet was washed twice with PBS to remove unbound antibody, and was incubated with phycoerythrin-labeled $F\left(a b^{\prime}\right) 2$ anti-IgG fragments (secondary antibody) in the dark and on ice. Control staining was performed with isotype antibodies and with secondary antibody alone to measure background fluorescence. Cells were washed twice, resuspended in PBS, kept on ice, and immediately analyzed on a fluorescence-activated cell sorter (FACS) (Calibur, BD Biosciences, Franklin Lakes, NJ, U.S.A.). All antibodies were from Serotec (Raleigh, NC, U.S.A.). Apoptotic cells and necrotic cells were detected by annexin V and propidium iodide staining (30) (BD PharMingen, San Diego, CA, U.S.A.). Apoptotic and necrotic cells expose the inner cell membrane, allowing annexin $\mathrm{V}$ to bind to phosphatidylserine. Cell aliquots were stained with fluorescent labeled annexin $\mathrm{V}$ and counterstained with proprium iodide to detect necrotic cells.

Cytokine $\boldsymbol{m} \boldsymbol{R} \boldsymbol{N}$ A. Total RNA was isolated from tissue from the right lower lobe and from cell pellets of BALF by guanidinium thiocyanate-phenol-chloroform extraction. Ribonuclease protection assays were performed with total RNA from lung tissue and cell pellets (18). Briefly, cRNA transcripts of ovine interleukins (IL-1 $\beta$, IL-6, IL-8, IL-10), tumor necrosis factor (TNF- $\alpha$ ), and ovine ribosomal protein $\mathrm{L} 32$ as a reference RNA were synthesized with $\left({ }^{32} \mathrm{P}\right)$ uridine triphosphate (Lifesciences Products, Boston, MA, U.S.A.) using SP6 or T7 polymerase (ribonuclease protection assay 111: Ambion, Austin, TX, U.S.A.). Aliquots of $10 \mu \mathrm{g}$ RNA were incubated with excess radiolabeled probes for cytokines and $\mathrm{L} 32$ at $55^{\circ} \mathrm{C}$ for $18 \mathrm{~h}$. The remaining single-stranded RNA was digested with RNAse A/TI (Ambion). Protected fragments were electrophoresed on a $6 \%$ polyacrylamide-urea sequencing gel and visualized by autoradiography. Densities of the protected bands were quantified on a Phosphorimager (Molecular Dynamics, Sunnyvale, CA, U.S.A.), using ImageQuant Software (Molecular Dynamics). Due to the limited material, mRNA for only
IL-1 $\beta$, IL-6, and IL-8 were analyzed for BALF cells. There are no cytokine assays commercially available for sheep. We therefore chose to examine the cytokine mRNA based on the relevance to clinical studies and animal models of $\operatorname{BPD}(3,8$, $12,31)$.

mRNA for surfactant proteins and Sat PC. Surfactant protein mRNA were measured using RNAase protection assays as previously described (32). Briefly, an excess of linearized probes for ovine SP-A, SP-B, and SP-C and L32 that were 5' end $\left({ }^{32} \mathrm{P}\right)$ labeled were hybridized at $55^{\circ} \mathrm{C}$ with $3 \mu \mathrm{g}$ of total RNA from lung tissue. SP-D was quantified in a separate assay with $10 \mu \mathrm{g}$ total RNA. The probe for SP-D was a gift of Dr. Hallman, University of Oulu, Finland. After incubation with S1 nuclease, the protected fragments were resolved on $6 \%$ polyacrylamide 8 -mol urea sequencing gels, visualized by autoradiography, and quantified (32).

Sat PC was isolated from chloroform-methanol (2:1) extracts of BALF by neutral alumina column chromatography after exposure of lipid extracts to osmium tetroxide (33). Sat PC was quantified by phosphorus assay (34).

Lung morphology, inflammation score. The right upper lobe was inflation fixed at $30 \mathrm{~cm} \mathrm{H}_{2} \mathrm{O}$ pressure with $10 \%$ formalin. Paraffin tissue sections of $5 \mu \mathrm{m}$ thickness, stained with hematoxylin and eosin, were graded for the degree of inflammation by scoring three sections from each animal in a blinded fashion $(18,19,35)$. The score was 0 if there were no inflammatory cells in tissue or airspaces; 1 if a few cells were identified; 2 if a moderate cell infiltration was present, and 3 if there were large numbers of inflammatory cells in airspaces and tissue. Airspaces and tissue were assessed separately. Average scores were calculated for each animal.

Data analysis. Results are given as mean \pm SEM. Analysis of variance followed by the Student-Newman-Keuls multiple comparison procedure was used for comparisons of the 4 groups. Two-tailed unpaired t-tests were used for two group comparison. Significance was accepted at $p<0.05$.

\section{RESULTS}

Description of lambs and lung function. Five or six lambs were in each group and there were no differences in body weights or the ratios of thymus to body weight (Table 1).

Table 1. Comparison of animals

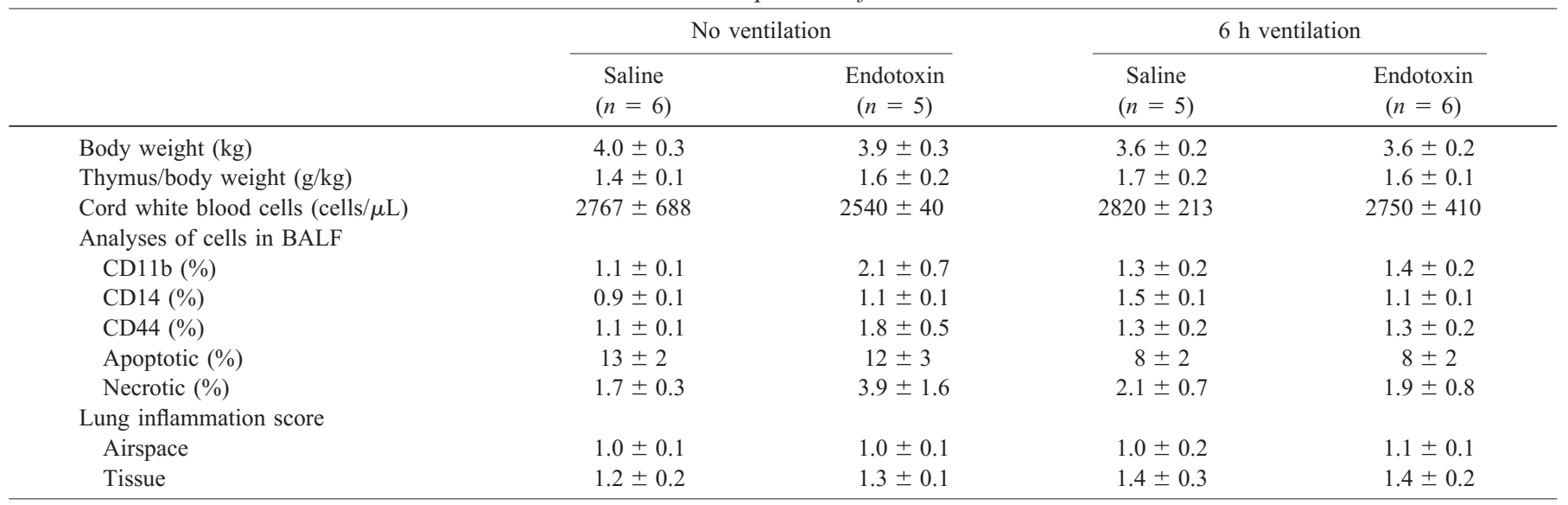


White blood cell numbers in cord blood also were similar. Inflammatory cell numbers (monocytes, lymphocytes, and neutrophils) in fetal lung fluid were 7 times higher in the endotoxin group $\left(22 \pm 5 \times 10^{3} / \mathrm{mL}\right)$ than in the saline group $(3 \pm 1 \times$ $\left.10^{3} / \mathrm{mL}\right)(p<0.05)$.

The target $\mathrm{V}$, $\mathrm{PCO}_{2}$, and $\mathrm{PO}_{2}$ values were achieved for the endotoxin-exposed and saline-treated and ventilated groups with similar ventilatory pressures (Table 2 ). $\mathrm{FiO}_{2}$ varied from 0.4 to 1.0 , and there were no significant differences between two ventilated groups. Sequential compliance and VEI measurements demonstrated similar lung mechanics and gas exchange between control and the endotoxin exposed lambs (Fig. 1). The deflation limbs of the pressure volume curves also were similar.

Indicators of inflammation. Total protein in BALF for the No Vent groups was not different (Fig. 2A). The total protein for the $6 \mathrm{~h}$ Vent groups was about 2-fold higher than for the No Vent groups, but the antecedent endotoxin exposure did not significantly increase the protein recovery. The total number of inflammatory cells in the BALF of the saline-exposed No Vent group were $6 \pm 1 \times 10^{5} / \mathrm{kg}$ body weight and were $10 \pm 3 \times$ $10^{5} / \mathrm{kg}$ body weight in the endotoxin-exposed No Vent group, values that were not different (Fig. $2 B$ ). The inflammatory cells in BAL were significantly increased relative to the No Vent groups for both the saline and the endotoxin exposed lambs after $6 \mathrm{~h}$ ventilation $(p<0.05)$. Hydrogen peroxide was not detectable in BALF cells from the No Vent groups (Fig. 2C). Over $200 \mu \mathrm{M} / \mathrm{kg}$ of hydrogen peroxide was measured for both $6 \mathrm{~h}$ Vent groups, with the endotoxin-exposed animals having the higher mean value of $500 \mu \mathrm{M} / \mathrm{kg}$. Neutrophils were increased for both the saline- and endotoxin-exposed lambs that were ventilated relative to the No Vent groups; however, there was not a significant increase in neutrophils in the endotoxinexposed and ventilated lambs relative to the control lambs (Fig. 3). Lymphocytes and monocytes were increased significantly in endotoxin-exposed lambs after ventilation in comparison to unventilated groups and the ventilated saline controls.

Endotoxin exposure did not alter the low cytokine mRNA expression in the lung tissue or by the cells recovered by BALF in the No Vent animals (Fig. 4). Six hours of ventilation increased IL-1 $\beta$, IL-6, and IL-8 mRNA expression in the lung tissue from both the ventilated groups of animals. IL- 8 mRNA expression was higher in the lung tissue in the ventilated and endotoxin-exposed group than in the saline-treated ventilated

Table 2. Ventilation variables

\begin{tabular}{|c|c|c|}
\hline & Saline & Endotoxin \\
\hline \multicolumn{3}{|c|}{$\mathrm{V}_{\mathrm{T}}(\mathrm{mL} / \mathrm{kg})$} \\
\hline $1 \mathrm{~h}$ & $9.4 \pm 0.7$ & $8.8 \pm 0.6$ \\
\hline $6 \mathrm{~h}$ & $8.1 \pm 0.5$ & $8.1 \pm 0.3$ \\
\hline \multicolumn{3}{|c|}{$\mathrm{PCO}_{2}(\mathrm{~mm} \mathrm{Hg})$} \\
\hline $1 \mathrm{~h}$ & $44 \pm 4$ & $45 \pm 4$ \\
\hline $6 \mathrm{~h}$ & $54 \pm 6$ & $65 \pm 7$ \\
\hline \multicolumn{3}{|c|}{$\mathrm{Po}_{2}(\mathrm{~mm} \mathrm{Hg})$} \\
\hline $1 \mathrm{~h}$ & $190 \pm 33$ & $183 \pm 33$ \\
\hline $6 \mathrm{~h}$ & $153 \pm 21$ & $119 \pm 31$ \\
\hline \multicolumn{3}{|c|}{ Ventilatory pressure $\left(\mathrm{cm} \mathrm{H}_{2} \mathrm{O}\right)$} \\
\hline $1 \mathrm{~h}$ & $22 \pm 1$ & $23 \pm 2$ \\
\hline $6 \mathrm{~h}$ & $17 \pm 1$ & $19 \pm 1$ \\
\hline
\end{tabular}
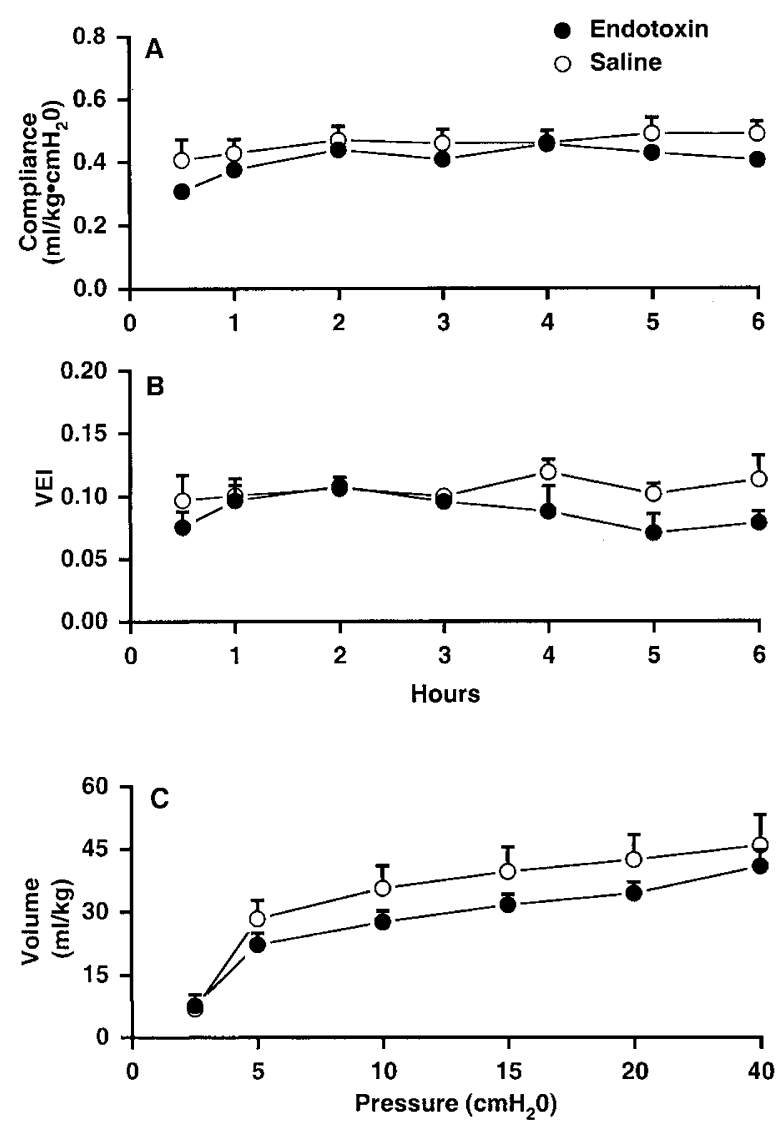

Figure 1. Compliance $(A)$, VEI $(B)$, and lung gas volumes measured for the deflation limbs of pressure-volume curves $(C)$. There was no difference in the measurements of lung function over the 6-h ventilation period.

group $(p<0.05)$. The mRNA for IL- 6 and IL- 8 was increased in the alveolar cells from the endotoxin-exposed and ventilated lambs relative to all other groups. IL- $1 \beta$ mRNA expression was also increased over 40 -fold for this group, although the difference was not significant because of the wide variance of the measurement.

There was no differential cell activation detected for CD11b, $\mathrm{CD} 14$, and CD44, nor changes in percentage of apoptotic cells and percentage of necrotic for cells from BALF between the four groups (Table 1). The inflammatory score measured on histologic sections from the right upper lobes was low and there were no differences between groups. No morphologic differences were seen between endotoxin and saline groups (data not shown).

Surfactant. The No Vent animals were not treated with surfactant and the amounts of Sat PC in BALF of the saline controls $(0.47 \pm 0.20 \mu \mathrm{mol} / \mathrm{kg})$ and the endotoxin-exposed lambs $(0.57 \pm 0.26 \mu \mathrm{mol} / \mathrm{kg})$ were low. These low Sat PC levels indicate that these lamb lungs were very immature and endotoxin did not change surfactant Sat PC level. The amount of Sat PC in the lung tissue of the endotoxin-exposed and unventilated lambs $(65 \pm 14 \mu \mathrm{mol} / \mathrm{kg})$ was not different from control lambs $(51 \pm 5 \mu \mathrm{mol} / \mathrm{kg})$. Relative to the mRNA for the surfactant proteins for the No Vent control lambs, endotoxin exposure $30 \mathrm{~d}$ before delivery had no effect (Fig. 5). The mRNA for SP-A, SP-B, and SP-D tended to increase for the $6 \mathrm{~h}$ 

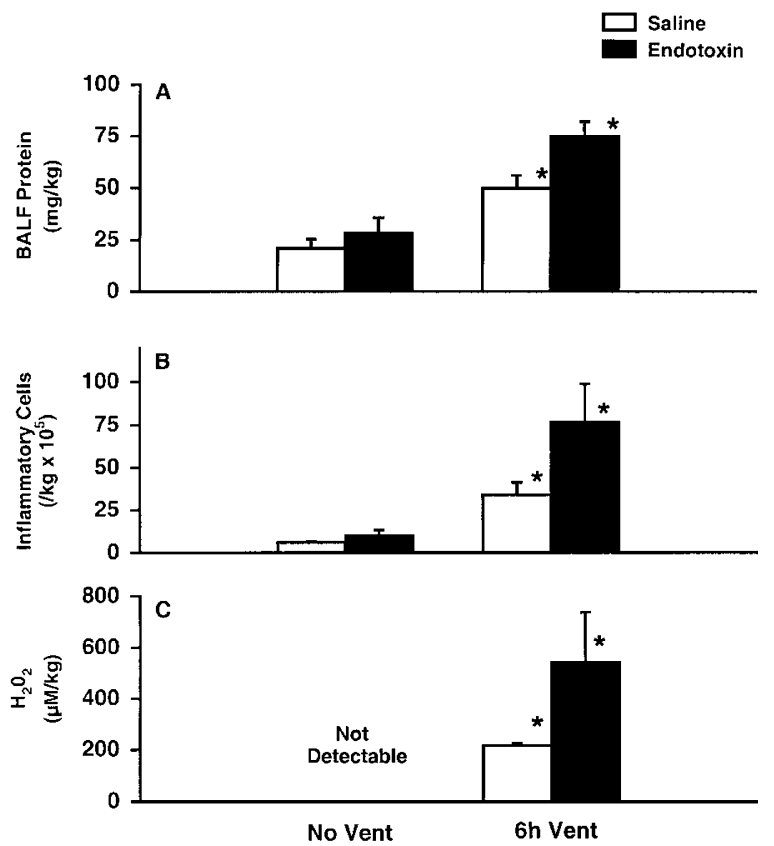

Figure 2. Protein in BALF $(A)$, inflammatory cells $(B)$, and hydrogen peroxide production by cells from BALF $(C)$ expressed as per kilogram body weight. There were no differences in BALF protein or cells in the BALF between the two nonventilated (Non Vent) groups. Hydrogen peroxide was not detectable for the Non Vent animals. After $6 \mathrm{~h}$ ventilation $(6 \mathrm{~h} \mathrm{Vent})$ the protein, cell numbers, and hydrogen peroxide were increased for both antenatal saline- and endotoxin-exposed lambs relative to the Non Vent groups ${ }^{*} p<$ $0.05)$.

Vent groups, with a 3-fold increase in SP-D in the $6 \mathrm{~h}$ Vent endotoxin-exposed groups being the only significant increase.

\section{DISCUSSION}

The antenatal exposure to endotoxin $30 \mathrm{~d}$ before preterm delivery increased the number of inflammatory cells in fetal lung fluid but had no other detectable effect on the fetal lung. These cells in fetal lung fluid may be cells from amniotic fluid that can mix with the fetal lung fluid. The indicators of maturation - amount of Sat PC, mRNA for surfactant proteins, or the appearance of the lung - were not altered by this single $10 \mathrm{mg}$ early gestation endotoxin exposure. Nevertheless, the lung was primed by endotoxin exposure because the mild indicators of injury induced by mechanical ventilation in the saline-exposed preterm were amplified in the lambs exposed to the endotoxin $30 \mathrm{~d}$ before delivery.

Many infants born before $30 \mathrm{wk}$ gestation have been exposed to an asymptomatic indolent histologic chorioamnionitis, whereas others are exposed to a more acute symptomatic chorioamnionitis (14). Although most fetuses in preterm labor are now treated with antibiotics (14), it is unlikely that the antibiotics can fully suppress the inflammatory response. In general, antibiotics do not delay preterm delivery (36). Therefore, the preterm fetus exposed to chorioamnionitis will have inflammatory stimuli until delivery occurs. Exposure of the fetal sheep to $20 \mathrm{mg}$ endotoxin for periods up to $15 \mathrm{~d}$ before preterm delivery caused chorioamnionitis, with persistent increases in inflammatory cells in BALF and indicators of lung

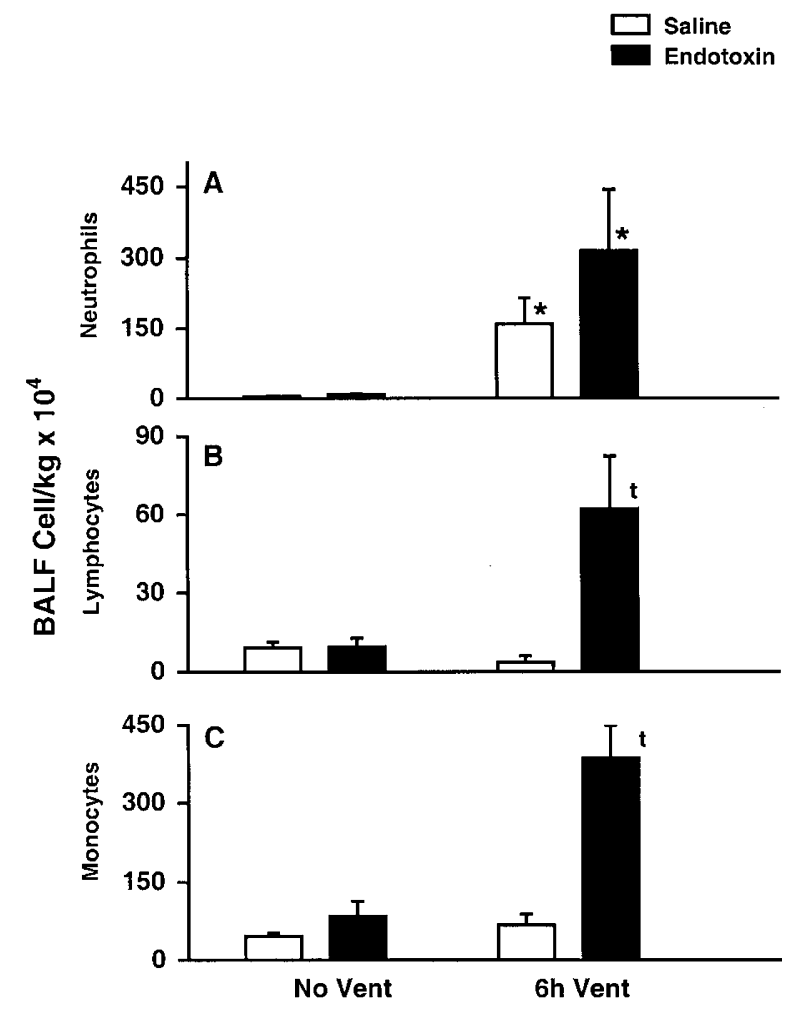

Figure 3. Neutrophils $(A)$, lymphocytes $(B)$, and monocytes $(C)$ in BALF samples from lambs that were not ventilated (No Vent) and ventilated for $6 \mathrm{~h}$ $(6 \mathrm{~h} \mathrm{Vent})$. There were no differences in cell numbers without ventilation. After $6 \mathrm{~h}$ Vent, the antenatal endotoxin-exposed lambs had more lymphocytes and monocytes than all other groups $\left({ }^{t} p<0.01\right)$. Neutrophils were increased for both of the $6 \mathrm{~h}$ Vent groups relative to the No Vent groups $\left({ }^{*} p<0.01\right)$.

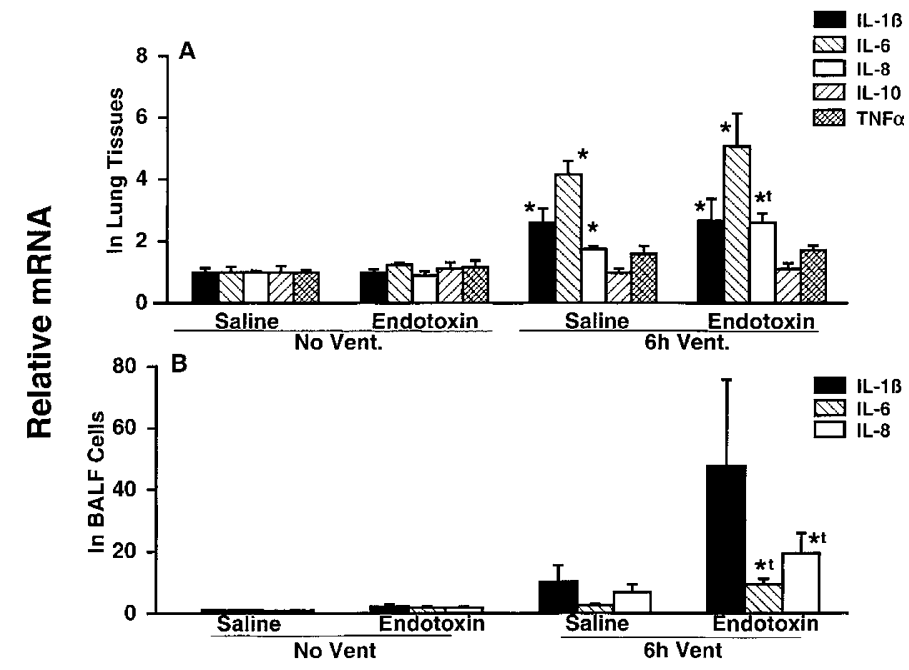

Figure 4. Cytokine mRNA expression in lung tissue $(A)$ and cells from BALF $(B)$ expressed relative to L32. The antenatal endotoxin did not change cytokine mRNA expression in lung tissue or alveolar cells relative to the no ventilation (No Vent) saline group. Six hours of ventilation ( $6 \mathrm{~h} \mathrm{Vent})$ resulted in increased IL-1 $\beta$, IL-6, and IL-8 mRNAs in lung tissue for both the saline and endotoxin groups. IL- 6 and IL- 8 mRNA were increased in cells from the BALF in the $6 \mathrm{~h}$ Vent and endotoxin-exposed group $v s$ all other groups $\left({ }^{*} p<0.05 v s\right.$ saline and endotoxin No Vent groups; ${ }^{\mathrm{t}} p<0.05 v s$ saline $6 \mathrm{~h}$ Vent group).

maturation $(18,21)$. For this experiment, we wanted to test whether the lung could be primed with an early, prenatal inflammatory stimulus that would alter inflammatory response 


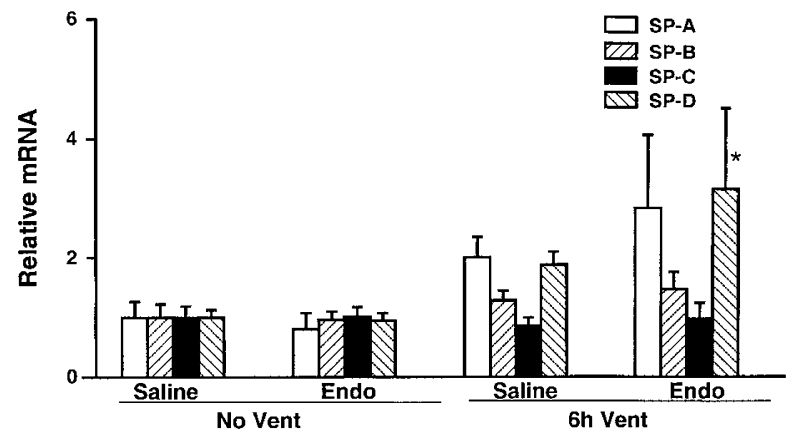

Figure 5. Expression of surfactant protein mRNA for all groups relative to the nonventilated (No Vent) saline group that was given a value of 1 . The antenatal endotoxin exposure resulted in increased SP-D mRNA after $6 \mathrm{~h}$ of ventilation (6 h Vent) $\left({ }^{*} p<0.05\right.$ vs No Vent groups).

of the lung to postnatal mechanical ventilation. We chose 10 $\mathrm{mg}$ endotoxin given to the amniotic cavity such that we did not get much residual inflammation in the lungs or increased surfactant after the $30 \mathrm{~d}$ interval. Endotoxin was chosen as a representative proinflammatory, although the common causes of indolent chorioamnionitis are commensal organisms such as Ureaplasma urealyticum (14). However, Ureaplasma in the amniotic cavity does cause inflammation and cytokine production (37).

We treated the ventilated lambs with surfactant to avoid possible differences in lung function and to minimize the injurious stimulus of the initiation of mechanical ventilation $(26,38,39)$. This experiment was an extreme test of the ability of the preterm lung to amplify an inflammatory response because the inflammatory exposure occurred $30 \mathrm{~d}$ before the preterm delivery and the postnatal ventilation was designed to minimize injury. This study design is both a strength and a weakness of the study. We did not evaluate the effects of ventilation on the premature lamb with chorioamnionitis at delivery, which might result in more striking effects on the fetal lung. The analogous situation would be endotoxin exposure just before mechanical ventilation of the adult lung, which does amplify the inflammatory response (40). We used a lower dose and longer interval from intra-amniotic exposure to delivery to minimize residual lung inflammation, maturation effects, and effects on alveolar development (18). That strategy together with the use of surfactant treatment and a ventilation style designed to minimize lung injury was selected to avoid the confounding effects of altered lung function on our ability to interpret the inflammation data. We recognize that other doses of endotoxin, intervals from fetal exposure to delivery, and gestations at delivery may result in different responses to the initiation of mechanical ventilation.

Our results may be helpful in understanding the variable progression of infants toward BPD after birth. Traditionally, infants who have severe respiratory distress syndrome and require prolonged mechanical ventilation and oxygen exposure are thought to develop BPD because of their postnatal ventilatory care (41). In contrast, some infants have minimal lung disease after birth but then progress to BPD without the history of mechanical ventilation and supplemental oxygen exposure (42). This experiment in fetal sheep demonstrates that a history of antenatal inflammation distant in time from the preterm delivery can alter the subsequent pulmonary responses. Watterberg et al. (17) found increased proinflammatory mediators in airway samples of infants without respiratory distress syndrome that subsequently developed BPD. Future clinical studies that focus on the characterization of the degree of fetal inflammation before delivery should help better define the relationships between fetal status and BPD.

Neutrophils are the inflammatory cell type most associated with acute lung injury in the adult lung (43). Neutrophils are increased in airway samples from infants destined to develop BPD (8). Although the numbers of neutrophils did not increase in the alveolar lavages of the endotoxin-exposed lambs relative to the controls, the large changes after $6 \mathrm{~h}$ of ventilation were a 12-fold increase in lymphocytes and a 5.7-fold increase in monocytes. The normal preterm lung has very few lymphocytes or monocytes in the airspaces (44). The numbers of monocytes and lymphocytes were not increased in the endotoxin-exposed lung that was not ventilated relative to the control. However, the antenatal endotoxin increased the monocyte/macrophage population recruited to the airspaces by mechanical ventilation. Because the resident macrophages are the first cells that respond to injury or inflammatory stimuli, the antenatal endotoxin augmented the innate immune response of the preterm lung. Macrophages are a significant source of neutrophil chemokines such as IL-8 and growth related oncogene-alpha $(\mathrm{GRO} \alpha)$, and this may be reflected by the higher IL-8 mRNA we observed in BALF cells from the endotoxintreated group. The increased number of lymphocytes indicates a residual immune response in the fetal lung. The nature of this lymphocyte response is not known, but it may be important to the subsequent immune responses of the lung.

The amount of Sat PC and the mRNA for the surfactant proteins was not increased in this model. The amount of Sat PC in the BALF and lung tissue also was low. Higher-dose endotoxin exposure more proximal to delivery can cause large increases in both the Sat PC and the surfactant proteins (21, 32). Similarly, chronic ventilation of preterm baboons results in large increases in tissue pools of surfactant components, although alveolar pools are low, suggesting a problem with secretion $(45,46)$. Ventilation $30 \mathrm{~d}$ after intra-amniotic endotoxin induced only an increase in SP-D mRNA. As with the increased lymphocytes, this is consistent with a stimulation of innate host response as this protein modulates inflammation in the lungs (47).

This experiment was not designed to mimic a common clinical situation. The goal was to probe the responses of the lung to a transient chorioamnionitis at the saccular stage of lung development. We found that the endotoxin exposure augmented the postnatal inflammatory response to mechanical ventilation. Other immune functions such as monocytemediated antigen processing also may be changed. Antenatal inflammatory exposure may confer the risk of exaggerating later inflammatory responsiveness in the preterm lung.

\section{REFERENCES}

1. Hussain NA, Siddiqui NH, Stocker JR 1998 Pathology of arrested acinar development in postsurfactant bronchopulmonary dysplasia. Hum Pathol 29:710-717 
2. Thibeault DW, Mabry SM, Ekekezie I, Truog WE 2000 Lung elastic tissue maturation and perturbations during the evolution of chronic lung disease. Pediatrics 106:1452-1459

3. Coalson JJ 2000 Pathology of chronic lung disease of early infancy. In: Bland RD, Coalson JJ (eds) Chronic Lung Disease in Early Infancy. Marcel Dekker, New York, pp $85-124$

4. Jobe AH, Ikegami M 2001 Antenatal infection/inflammation and postnatal lung maturation and injury. Respir Res 2:27-32

5. Coalson JJ, Winter VT, Siler-Khodr T, Yoder BA 1999 Neonatal chronic lung disease in extremely immature baboons. Am J Respir Crit Care Med 160:1333-1346

6. Albertine KH, Jones GP, Starcher BC, Bohnsack JF, Davis PL, Cho S, Carlton DP, Bland RD 1999 Chronic lung injury in preterm lambs. Am J Respir Crit Care Med 159:945-958

7. Warner BB, Stuart LA, Papes RA, Wispe JR 1998 Functional and pathological effects of prolonged hyperoxia in neonatal mice. Am J Physiol 275:L110-L117

8. Speer CP, Groneck P 1998 Oxygen radicals, cytokines, adhesion molecules and lung injury in neonates. Semin Neonatol 3:219-228

9. Merritt TA, Cochrane CG, Holcomb K, Bohl B, Hallman M, Strayer D, Edwards III DK, Gluck L 1983 Elastase and alpha 1-proteinase inhibitor activity in tracheal aspirates during respiratory distress syndrome. Role of inflammation in the pathogenesis of bronchopulmonary dysplasia. J Clin Invest 72:656-666

10. Ogden BE, Murphy S, Saunders GC, Johnson JD 1983 Lung lavage of newborns with respiratory distress syndrome. Prolonged neutrophil influx is associated with bronchopulmonary dysplasia. Chest 83:31S-33S

11. Jobe A, Bancalari E 2001 NICHD/NHLBI/ORD workshop summary-bronchopulmonary dysplasia. Am J Respir Crit Care Med 163:1723-1729

12. Naik AS, Kallapur SG, Bachurski CJ, Jobe AH, Michna J, Kramer BW, Ikegami M 2001 Effects of ventilation with different positive end-expiratory pressures on cytokine expression in the preterm lamb lung. Am J Respir Crit Care Med 164:494-498

13. Merritt TA, Puccia JM, Stuard ID 1981 Cytologic evaluation of pulmonary effluent in neonates with respiratory distress syndrome and bronchopulmonary dysplasia. Acta Cytol 25:631-639

14. Goldenberg RL, Hauth JC, Andrews WW 2000 Intrauterine infection and preterm delivery. N Engl J Med 342:1500-1507

15. Alexander JM, Gilstrap LC, Cox SM, McIntire DM, Leveno KJ 1998 Clinical chorioamnionitis and the prognosis for very low birth weight infants. Obstet Gynecol 91:725-729

16. Gomez R, Romero R, Ghezzi F, Yoon BH, Mazor M, Berry SM 1998 The fetal inflammatory response syndrome. Am J Obstet Gynecol 179:194-202

17. Watterberg KL, Demers LM, Scott SM, Murphy S 1996 Chorioamnionitis and early lung inflammation in infants in whom bronchopulmonary dysplasia develops. Pediatrics 97:210-215

18. Kallapur SG, Willet KE, Jobe AH, Ikegami M, Bachurski C 2001 Intra-amniotic endotoxin: chorioamnionitis precedes lung maturation in preterm lambs. Am J Physiol 280:L527-L536

19. Kramer BW, Moss T, Willet K, Newnham J, Sly P, Kallapur SG, Ikegami M, Jobe A 2001 Dose and time response after intra-amniotic endotoxin in preterm lambs. Am J Respir Crit Care Med 164:982-988

20. Willet KE, Jobe AH, Ikegami M, Brennan S, Newnham J, Sly PD 2000 Antenatal endotoxin and glucocorticoid effects on lung morphometry in preterm lambs. Pediatr Res 48:782-788

21. Jobe AH, Newnham JP, Willet KE, Moss TJ, Ervin MG, Padbury JF, Sly PD, Ikegami M 2000 Endotoxin induced lung maturation in preterm lambs is not mediated by cortisol. Am J Respirt Crit Care Med 162:1656-1661

22. Tremblay L, Valenza F, Ribeiro SP, Li J, Slutsky AS 1997 Injurious ventilatory strategies increase cytokines and c-fos m-RNA expression in an isolated rat lung mode. J Clin Invest 99:944-952

23. Murphy DB, Cregg N, Tremblay L, Engelberts D, Laffey JG, Slutsky AS, Romaschin A, Kavanagh BP 2000 Adverse ventilatory strategy causes pulmonary-to-systemic translocation of endotoxin. Am J Respir Crit Care Med 162:27-33

24. Ikegami M, Jobe AH 2002 Injury responses to different surfactants in ventilated premature lamb lung. Pediatr Res 51:689-695

25. Michna J, Jobe AH, Ikegami M 1999 Positive end-expiratory pressure preserves surfactant function in preterm lambs. Am J Respir Crit Care Med 160:634-639
26. Wada K, Jobe AH, Ikegami M 1997 Tidal volume effects on surfactant treatment responses with the initiation of ventilation in preterm lambs. J Appl Physiol 83:10541061

27. Notter RH, Egan EA, Kwong MS, Holm BA, Shapiro DL 1985 Lung surfactant replacement in premature lambs with extracted lipids from bovine lung lavage: effects of dose, dispersion technique, and gestational age. Pediatr Res 19:569-577

28. Lowry OH, Rosebrough NJ, Farr AL, Randall RJ 1951 Protein measurement with the Folin phenol reagent. J Biol Chem 193:265-275

29. Weirich E, Rabin RL, Maldonado Y, Benitz W, Modler S, Herzenberg LA 1998 Neutrophil CD11b expression as a diagnostic marker for early-onset neonatal infection. J Pediatr 132:445-451

30. Vermes I, Haanen C, Steffens-Nakken H, Reutelingsperger C 1995 A novel assay for apoptosis. Flow cytometric detection of phosphatidylserine expression on early apoptotic cells using fluorescein labelled annexin V. J Immunol Methods 184:39-51

31. Yoon BH, Romero R, Jun JK, Park KH, Park JD, Ghezzi F, Kim BI 1997 Amniotic fluid cytokines (interleukin-6, tumor necrosis factor-alpha, interleukin-1 beta, and interleukin-8) and the risk for the development of bronchopulmonary dysplasia. Am J Obstet Gynecol 177:825-830

32. Bachurski CJ, Ross GF, Ikegami M, Kramer BW, Jobe AH 2001 Intra-amniotic endotoxin increases pulmonary surfactant components and induces SP-B processing in fetal sheep. Am J Physiol 280:L279-L285

33. Mason RJ, Nellenbogen J, Clements JA 1976 Isolation of disaturated phosphatidylcholine with osmium tetroxide. J Lipid Res 17:281-284

34. Bartlett GR 1959 Phosphorus assay in column chromatography. J Biol Chem $234: 466-468$

35. Willet K, Jobe A, Ikegami M, Brennan S, Newnham J, Sly P 2000 Antenatal endotoxin and glucocorticoid effects on lung morphometry in preterm lambs. Pediatr Res 48:782-788

36. Kenyon SL, Taylor DJ, Tarnow-Mordi W 2001 Broad-spectrum antibiotics for spontaneous preterm labour: the ORACLE II randomised trial. ORACLE Collaborative Group. Lancet 357:989-994

37. Yoon BH, Romero R, Park JS, Chang JW, Kim YA, Kim JC, Kim KS 1998 Microbial invasion of the amniotic cavity with Ureaplasma urealyticum is associated with a robust host in fetal, amniotic, and maternal compartments. Am J Obstet Gynecol 179:1254-1260

38. Carlton DP, Cho SC, Davis P, Lont M, Bland RD 1995 Surfactant treatment at birth reduces lung vascular injury and edema in preterm lambs. Pediatr Res 37:265-270

39. Ikegami M, Kallapur S, Michna J, Jobe AH 2000 Lung injury and surfactant metabolism after hyperventilation of premature lambs. Pediatr Res 47:398-404

40. Chiumello D, Pristine G, Slutsky AS 1999 Mechanical ventilation affects local and systemic cytokines in an animal model of acute respiratory distress syndrome. Am J Respir Crit Care Med 160:109-116

41. Bancalari E, Gonzalez A 2000 Clinical course and lung function abnormalities during development of neonatal chronic lung disease. In: Bland RD, Coalson JJ (eds) Chronic Lung Disease in Early Infancy. Marcel Dekker, New York, pp 41-64

42. Charafeddine L, D'Angio CT, Phelps DL 1999 Atypical chronic lung disease patterns in neonates. Pediatrics 103:759-765

43. Kawano T, Mori S, Cybulsky M, Burger R, Ballin A, Cutz E, Bryan AC 1987 Effect of granulocyte depletion in a ventilated surfactant-depleted lung. J Appl Physiol 62:27-33

44. Jackson JC, Chi EY, Wilson CB, Truog WE, Teh EC, Hodson WA 1987 Sequence of inflammatory cell migration into lung during recovery from hyaline membrane disease in premature newborn monkeys. Am Rev Respir Dis 135:937-940

45. Seidner SR, Jobe AH, Coalson JJ, Ikegami M 1998 Abnormal surfactant metabolism and function in preterm ventilated baboons. Am J Respir Crit Care Med 158:19821989

46. Awasthi S, Coalson JJ, Crouch E, Yang F, King RJ 1999 Surfactant proteins A and $\mathrm{D}$ in premature baboons with chronic lung injury. Evidence for an inhibition of secretion. Am J Respir Crit Care Med 160:942-949

47. Mason RJ, Greene K, Voelker DR 1998 Surfactant protein A and surfactant protein D in health and disease. Am J Physiol 275:L1-L13 